\title{
Analisis Faktor-Faktor Yang Dapat Memprediksi Financial Distress Pada Badan Penyelenggara Jaminan Sosial (BPJS) Kesehatan Tahun 2014-2018
}

\author{
Etsa Indria Prasetyo ${ }^{1}$, Teguh Prasetio $^{2}$, Dalizanolo Hulu ${ }^{3}$ \\ ${ }^{1,2,3}$ Departments of Management, Universitas Pembangunan Jaya \\ South Tangerang, Banten 15413, Indonesia \\ teguh.prasetio@upj.ac.id
}

Received 27 January 2020, Revised 13 March 2020, Accepted 20 March 2020

\begin{abstract}
The Social Insurance Administration Organization (BPJS) is a government agency that provide health services in the form of comprehensive health insurance for all Indonesian people. In the five years of implementation (2014-2018), the national health insurance program $(J K N)$ has provided benefits for the community. However, the financial statements of the JKN program show that there are financial problems which more precisely show signs of financial distress. This study aims to determine the factors that influence the results of financial distress prediction on BPJS Health so that it can provide advice on financial distress in maintaining the continuity of BPJS Health. To predict financial distress, this study uses the Altman model ( $Z$ Score) using data source from the 2014-2018 BPJS Health financial report. The results of this study are internal factors (high financial costs and participant contributions) affect financial distress and external factors (BPJS participants and government intervention) influence financial distress.
\end{abstract}

Keywords: Financial Distress, Altman (Z Score), Internal Factors, External Factors

\begin{abstract}
Abstrak - Badan Penyelenggara Jaminan Sosial (BPJS) merupakan program pemerintah yang bertujuan memberikan pelayanan kesehatan dalam bentuk jaminan kesehatan yang menyeluruh bagi seluruh rakyat Indonesia. Dalam lima tahun pelaksanaannya (2014-2018), program jaminan kesehatan nasional (JKN) telah memberikan manfaat bagi masyarakat. Namun, laporan keuangan program JKN menunjukan adanya permasalahan financial yang lebih tepatnya menunjukan tandatanda financial distress. Penelitian ini bertujuan untuk mengetahui faktor-faktor yang mempengaruhi dari hasil prediksi financial distress pada BPJS Kesehatan sehingga dapat memberikan saran mengenai financial distress dalam menjaga keberlangsungan BPJS Kesehatan. Untuk memprediksi financial distress penelitian ini menggunakan model Altman (Z Score) dengan menggunakan data yang bersumber dari laporan keuangan BPJS Kesehatan tahun 2014-2018. Hasil dari penelitian ini adalah faktor internal (biaya financial yang tinggi dan iuran peserta) berpengaruh terhadap financial distress dan faktor eksternal (peserta BPJS dan campur tangan pemerintah) berpengaruh terhadap financial distress.

Kata Kunci: Financial Distress, Altman (Z Score), Faktor Internal, Faktor Eksternal
\end{abstract}

\section{PENDAHULUAN}

Fenomena pelayanan kesehatan di Indonesia saat ini ditunjukkan dengan masih rendahnya aksesibilitas terhadap pelayanan kesehatan bagi masyarakat golongan ekonomi rendah, baik di perkotaan maupun di perdesaan. Faktor utama yang menyulitkan akses terhadap layanan kesehatan tersebut adalah faktor finansial. Beberapa peristiwa dapat dikemukakan bagaimana masyarakat ekonomi rendah terpaksa tidak dapat memperoleh layanan pengobatan yang memadai karena terlambat dibawa ke fasilitas kesehatan atau rumah sakit akibat ketiadaan uang untuk membayar biaya pengobatan maupun transportasi menuju fasilitas kesehatan. Akibatnya mereka membiarkan penyakitnya tak tertangani, semakin parah, dan sampai kehilangan nyawa.
Di sisi lain, pemerintah memiliki kewajiban untuk menjamin kesejahteraan masyarakatnya, termasuk dengan menjamin ketersediaan layanan kesehatan. Kewajiban pemerintah tertuang di dalam pasal 28 ayat (1) Undang-Undang Dasar Negara Republik Indonesia Tahun 1945. Pasal ini menegaskan bahwa setiap warga negara berhak hidup sejahtera lahir dan batin, bertempat tinggal dan mendapatkan lingkungan hidup yang baik dan sehat serta berhak mendapatkan layanan kesehatan.

Untuk mewujudkan amanat Undang-undang, Pemerintah Negara Republik Indonesia melalui Kementerian Kesehatan Republik Indonesia sejak 1 Januari 2014 telah meluncurkan program di bidang kesehatan berupa Jaminan Kesehatan Nasional untuk menjamin kesehatan masyarakat. Program tersebut didirikan melalui Badan Penyelenggara Jaminan 
Sosial (BPJS) yang menyelenggarakan Jaminan Kesehatan Nasional (JKN).

Penyelenggaraan program layanan kesehatan melalui BPJS menuntut adanya partisipasi aktif seluruh warga negara dengan menggunakan prinsip subsidi silang. Untuk itu seluruh Warga Negara Indonesia (WNI) wajib menjadi peserta jaminan kesehatan yang dikelola oleh BPJS Kesehatan. Tidak hanya WNI, orang asing yang telah bekerja sedikitnya enam bulan di Indonesia juga wajib membayar iuran. Kepesertaan BPJS Kesehatan ini bersifat wajib, meskipun yang bersangkutan sudah memiliki Jaminan Kesehatan lain.

Tabel 1. Cakupan Kepesertaan

\begin{tabular}{cc}
\hline Tahun & Cakupan Kepesertaan \\
\hline 2014 & 133.423 .653 \\
2015 & 156.790 .287 \\
2016 & 171.939 .254 \\
2017 & 187.982 .949 \\
2018 & 208.254 .199 \\
\hline
\end{tabular}

Sumber: Data Cakupan Kepersertaan 2018

Pada Tabel 1 terlihat bahwa jumlah peserta BPJS Kesehatan terus meningkat signifikan. Pada tahun 2014 jumlah peserta JKN baru mencapai 133 juta lebih jiwa, maka di tahun 2018 telah mencapai 208 juta lebih jiwa atau bertambah lebih dari 75 juta jiwa. Data pada Tabel 1 sekalipun menunjukkan kenaikan, namun belum mencapai target sesuai Rencana Pembangunan Jangka Menegah Nasional (RPJMN) 2015-2019. Pada RPJMN 2015-2019 pemerintah menargetkan Indonesia akan mencapai Universal Health Coverage (UHC) atau cakupan kesehatan menyeluruh bagi seluruh penduduk Indonesia pada 1 Januari 2019.

Dalam konteks UHC, cakupan layanan kesehatan seharusnya minimal mencapai $95 \%$ dari total penduduk. BPJS Kesehatan masih belum mencapai target tersebut. Salah satu kemungkinan penyebab peserta BPJS Kesehatan masih belum optimal adalah kontribusi berupa iuran peserta yang konsisten akan memegang peran penting dalam aktivitas pelayanan. Justru di sana masih terdapat permasalahan yang hingga kini masih belum terpecahkan. BPJS Kesehatan belum mampu mendorong penerimaan iuran secara konsisten dari peserta JKN.

Di sisi lain terdapat pula penelitian yang menunjukkan adanya kendala terkait kesiapan stakeholder untuk menyiapkan sarana dan prasarana kesehatan, baik di tingkat Puskesmas maupun Rumah Sakit. Kurangnya sosialisasi kepada pihak penyedia fasilitas pelayanan kesehatan yang menyebabkan hal tersebut terjadi (Irwandy, 2016).

Pola hubungan antara faktor-faktor internal dan eksternal terhadap pemanfaatan Jaminan Kesehatan Nasional terutama di keluarga miskin juga berkontribusi terhadap masalah yang dihadapi BPJS Kesehatan (Kurniawan, 2017). Berbagai permasalahan yang telah dikemukakan membawa kepada kekhawatiran BPJS Kesehatan akan mengalami kesulitan keuangan (financial distress) dan jika tidak diatasi dapat berdampak kepada kebangkrutan.

Atmaja (2008) mengemukakan bahwa financial distress merupakan kondisi perusahaan yang mengalami kesulitan keuangan dan terancam bangkrut. Platt dan Platt (2002) mendefinisikan financial distress dari sisi proses, dimana perusahaan memasuki tahap penurunan kondisi keuangannya mengalami kebangkrutan ataupun likuidasi.

Dengan demikian, financial distress dapat menjadi prediksi atau sistem deteksi dini (early warning system) akan terjadinya situasi keuangan perusahaan yang mengakibatkan kebangkrutan. Sistem deteksi dini ini tidak hanya dapat diterapkan di perusahaan dengan kondisi keuangan kurang baik, akan tetapi juga dapat diterapkan pada perusahaan yang memiliki kondisi baik. Financial distress akan dapat mengingatkan perusahaan agar dapat mengambil tindakan dalam menghindari masalah dan memperbaiki sistem keuangan.

Tabel 2. Laporan Aktivitas Keuangan BPJS Kesehatan 2014-2018 (Dalam Jutaan Rupiah)

\begin{tabular}{lcrrrr}
\multicolumn{1}{c}{ Keterangan } & 2014 & 2015 & 2016 & 2017 & 2018 \\
\hline Pendapatan & & & & & \\
Iuran & 40.719 & 52.691 & 67.404 & 74.246 & 81.975 \\
Kontribusi BPJS & - & 1.071 & - & 3.600 & 10.256 \\
Hibah dari BPJS & - & 1.540 & 6.827 & 135.271 & - \\
Investasi & 731.632 & 118.596 & 111.041 & 150.941 & 20.387 \\
Lain-lain & 62.326 & 116.839 & 65.453 & 506.449 & 969.374 \\
Jumlah Pendapatan & 41.513 & 55.537 & 74.408 & 78.353 & 93.201 \\
Beban & & & & & \\
Jaminan Kesehatan & 42.658 & 57.109 & 67.247 & 84.444 & 94.296 \\
Cadangan Teknis & -579 & 3.437 & 2.140 & 4.113 & 6.324 \\
Operasional BPJS & 2.476 & 2.554 & 3.625 & 3.809 & 3.768 \\
Investasi & 134.872 & 27.457 & 14.018 & 28.216 & 2.075 \\
Penyisihan Piutang & 121.317 & 710.272 & 854.212 & 375.525 & 63.728 \\
Lain-lain & 10.590 & 10.290 & 18.115 & 449.627 & 498.688 \\
Jumlsh Beban & 44.822 & 61.297 & 73.899 & 92.817 & 104.888 \\
\hline Sumber: BPJS Kesehatan $2014-2018$ & & &
\end{tabular}

Nindita dan Nur (2014) menekankan bahwa financial distress juga dapat disebabkan adanya pengaruh dari dalam perusahaan (internal) maupun dari luar perusahaan (eksternal). Hal ini berarti tidak cukup bagi perusahaan hanya mampu menutupi atau menanggulangi masalah-masalah yang disebabkan oleh faktor internal. Perusahaan juga perlu mengantisipasi faktor eksternal perusahaan yang mempunyai kemungkinan menyebabkan financial distress. Radifan (2015) bahkan menyebutkan faktor eksternal perusahaan lebih kompleks untuk diantisipasi karena bersifat makro dan cakupannya lebih luas. Faktor eksternal yang dimaksud di antaranya adalah kebijakan pemerintah yang dapat menambah beban usaha yang ditanggung perusahaan.

Faktor internal yang dipertimbangkan dapat mempengaruhi financial distress pada BPJS Kesehatan dalam penelitian ini meliputi: rasio likuiditas, leverage dan profitabilitas dengan melalui model Altman Z-Score termodifikasi (Ramadhani \& 
Lukviarman, 2009). Selanjutnya faktor eksternal yang mempengaruhi financial distess pada BPJS Kesehatan meliputi pendekatan kepesertaan dan campur tangan pemerintah.

Terdapat berbagai model prediksi kebangkrutan perusahaan yang merupakan antisipasi atau sistem peringatan dini terhadap financial distress. Modelmodel tersebut dapat digunakan sebagai sarana untuk mengidentifikasi bahkan memperbaiki kondisi sebelum sampai pada kondisi krisis.

Penelitian ini menggunakan model Altman ZScore Modifikasi sebagai salah satu pengukuran prediksi kebangkrutan yang berkembang dari waktu ke waktu. Altman sebagai penggagas model bahkan terus menguji dan memperluas modelnya. Model Altman Z-Score Modifikasi ini menggunakan rasiorasio tertentu dalam rangka memprediksi risiko kebangkrutan sebuah perusahaan (Nugroho, Mawardi \& Dwi, 2012).

Di dalam formula Z-Score, terdapat variabelvariabel: Net Working Capital (Modal Kerja Bersih) to Total Assets (Total Aktiva), Retained Earnings (Laba Ditahan) to Total Assets, Earning Before Interest and Taxes (Laba sebelum Bunga dan Pajak) to Total Assets, Total Equity (Total Modal) to Total Debt Ratio (Total Rasio Hutang). Variabel-variabel tersebut pada dasarnya merupakan: rasio likuiditas, rasio leverage dan rasio profitabilitas yang dapat membantu mengetahui faktor internal yang akan memengaruhi financial distress.

Penelitian ini dibatasi hanya pada lingkup faktor-faktor yang mempengaruhi prediksi financial distress pada perusahaan BPJS Kesehatan dengan periode pengamatan tahun 2014 hingga 2018. Dan rumusan masalah dalam penelitian ini adalah:

1. Apakah faktor internal (biaya finansial yang tinggi) berpengaruh terhadap financial distress yang dihitung dengan model Altman (Z Score) pada Badan Penyelenggara Jaminan Sosial (BPJS) Kesehatan periode 2014 hingga 2018 ?

2. Apakah faktor internal: iuran peserta berpengaruh terhadap financial distress yang dihitung dengan model Altman ( $\mathrm{Z}$ Score) pada Badan Penyelenggara Jaminan Sosial (BPJS) Kesehatan periode 2014 hingga 2018 ?

3. Apakah faktor eksternal: peserta BPJS Kesehatan berpengaruh terhadap financial distress yang dihitung dengan model Altman ( $\mathrm{Z}$ Score) pada Badan Penyelenggara Jaminan Sosial (BPJS) Kesehatan periode 2014 hingga 2018 ?

4. Apakah faktor eksternal: campur tangan pemerintah berpengaruh terhadap financial distress yang dihitung dengan model Altman ( $\mathrm{Z}$ Score) pada Badan Penyelenggara Jaminan Sosial (BPJS) Kesehatan periode 2014 hingga 2018 ?

\section{Dampak Kondisi Financial Distress bagi Perusahaan \\ Terdapat lima tingkatan dampak kondisi financial distress (Anderson, 2013) yaitu:}

Pertama Negligible. Tingkatan ini terjadi ketika kondisi financial distress baru mulai terjadi, namun belum mengakar terlalu jauh. Dengan demikian masih dapat diabaikan.

Kedua Moderate. Tingkatan lanjutan dari tingkatan sebelumnya ketika kondisi kesulitan keuangan mulai memburuk.

Ketiga Severe. Tingkatan yang akan membawa kondisi perusahaan menjadi lebih parah jika kondisi kesulitan keuangan terus menerus terjadi.

Keempat Banckrupt. Tingkatan kesulitan keuangan yang sudah tidak dapat dilalui oleh perusahaan sehingga akan bangkrut.

Kelima Survival Issues. Tingkatan kondisi ketika perusahaan masih mengalami hal yang lebih buruk setelah bangkrut. Hal ini akan terkait masalah kelangsungan hidup bagi setiap individual.

\section{Model Altman (Z Score)}

Altman melakukan penelitian analisis diskriminan untuk mengembangkan model baru untuk memprediksi financial distress perusahaan. Model tersebut adalah Z-Score yang merupakan model linier dengan rasio keuangan yang diberi bobot sehingga memiliki kemampuan untuk memprediksi. Model ini pada dasarnya hendak mencari nilai $\mathrm{Z}$ yang menunjukan kondisi perusahaan serta mereflesikan prospek perusahaan mendatang.

Model Altman sebagai satu pengukuran financial distress terus berkembang. Pada tahun 1995, Altman mengubah modelnya dengan mengeliminasi variabel sales/total asset. Modifikasi model dilakukan agar dapat diterapkan pada semua perusahaan dengan rumus:

$$
\begin{aligned}
\text { Z-score }=3.25 & +6.56 \mathrm{X} 1+3.26 \mathrm{X} 2+6.72 \mathrm{X} 3 \\
& +1.05 \mathrm{X} 4
\end{aligned}
$$

Keterangan variabel: $\mathrm{X} 1=$ modal kerja/total aset, $\mathrm{X} 2$ = laba ditahan/total aset, X3 = penghasilan sebelum bunga dan pajak/total aset, dan $\mathrm{X} 4=$ nilai buku ekuitas/nilai buku total utang

Jika nilai Z-Score kurang dari 1.1 mengindikasikan perusahaan mengalami financial distress. Hal ini menuntut manajemen melakukan tindakan yang tepat agar perusahaan tidak mengalami kebangkrutan.

\section{KERANGKA PEMIKIRAN}

Kerangka penelitian ini digambarkan seperti dalam Gambar 1.

\section{METODE}

\section{Jenis Penelitian}

Penelitian ini adalah penelitian kuantitatif yang menekankan pada data-data numerikal (angka) diolah dengan metode statistika (Azwar, 2007) dengan menggunakan model pendekatan deskriptif. Pengertian deskriptif (Sugiyono, 2016) adalah metode yang berfungsi memberi gambaran terhadap 
objek yang diteliti tanpa melakukan analisis dan membuat kesimpulan yang berlaku umum melalui data atau sampel yang telah terkumpul sebagaimana adanya.

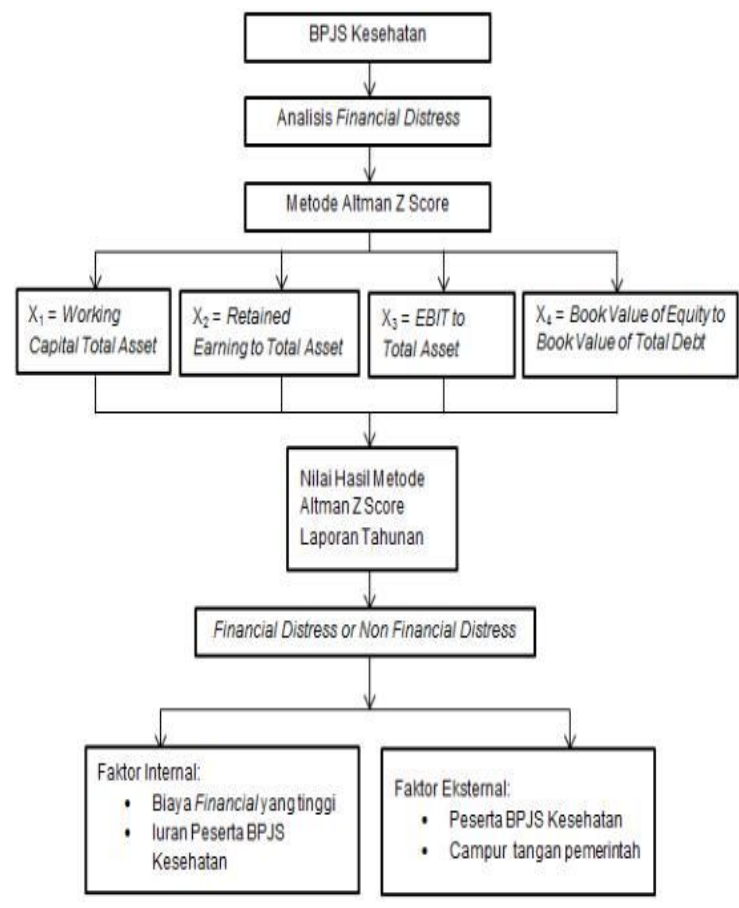

Gambar 1. Kerangka pemikiran

\section{Populasi dan Sampel}

Populasi yang digunakan dalam penelitian ini adalah kinerja keuangan perusahaan BPJS Kesehatan dalam kurun tahun 2014-2018.

Data yang digunakan adalah sumber data sekunder. Pertama, Laporan Pengelolaan Program dan Laporan Keuangan Tahunan BPJS Kesehatan pada tahun 2014 hingga 2018. Kedua, laporan posisi keuangan, laporan aktivitas dan laporan arus kas BPJS kesehatan pada tahun 2014-2018.

\section{Pengukuran Variabel}

Hasil pengukuran Z-Score akan dapat memberi indikasi sebagai berikut:

- Jika nilai Z > 2,6 maka perusahaan diprediksi sebagai sehat (tidak berpotensi bangkrut).

- Jika nilai 1,1 $<\mathrm{Z}<2,6$ maka perusahaan diprediksi sebagai area abu-abu.

- Jika nilai $\mathrm{Z}<1,1$ maka perusahaan diprediksi sebagai berpotensi akan mengalami kebangkrutan.

\section{Metode Analisis Data}

Penelitian ini mengukur financial distress dengan menggunakan rasio keuangan sesuai model Altman Z-Score terlebih dahulu. Setelah hasilnya diperoleh kemudian dilakukan perhitungan rasio keuangan dengan menggunakan Microsoft Excel. Selanjutnya dilakukan prediksi atas resiko kebangkrutan menggunakan perhitungan terhadap nilai Z-Score.

\section{HASIL DAN PEMBAHASAN}

\section{Net Working Capital to Total Assets (X1)}

Pada tahun 2014, rasio X1 sebesar -0,83. Hal ini berarti dari setiap Rp.1,00 total aset mampu dijamin oleh modal kerja sebesar $-0,83$.

Tabel 3. Perhitungan Rasio X1 pada BPJS Kesehatan 2014-2018 (Dalam Jutaan Rupiah)

\begin{tabular}{rrrr}
\hline Tahun & \multicolumn{1}{c}{ Modal Kerja } & \multicolumn{1}{l}{ Total Aset } & \multicolumn{1}{c}{ X1 } \\
\hline 2014 & 2.766 .515 & -3.309 .144 & $-0,836021$ \\
2015 & 419.367 & -9.069 .216 & $-0,046240$ \\
2016 & 3.157 .062 & -8.560 .782 & $-0,368782$ \\
2017 & -7.620 .402 & -23.025 .252 & 0,330958 \\
2018 & -10.249 .797 & -34.712 .814 & 0,295274 \\
\hline
\end{tabular}

Sumber: Data diolah dari BPJS

Di tahun 2015, rasio likuiditas mengalami kenaikan yang cukup besar dari tahun sebelumnya yaitu rasio X1 sebesar -0,04 yang artinya setiap Rp.1,00 total aset mampu dijamin oleh modal kerja sebesar $-0,04$.

Sementara pada tahun 2016, rasio likuiditas kembali mengalami penurunan dari tahun sebelumnya yaitu rasio X1 sebesar -0,37 yang artinya setiap Rp.1,00 total aset mampu dijamin oleh modal kerja sebesar $-0,37$.

Pada tahun 2017, rasio likuiditas X1 sebesar 0,33 yang artinya setiap Rp.1,00 total aset mampu dijamin oleh modal kerja sebesar 0,33.

Dan pada tahun 2018, rasio likuiditas mencapai 0,29 yang artinya setiap Rp.1,00 total aset mampu dijamin oleh modal kerja sebesar 0,29.

\section{Retained Earning to Total Assets (X2)}

Rasio X2 pada tahun 2014 menunjukkan nilai 1 yang artinya setiap Rp.1,00 Total Aset yang dimiliki oleh BPJS Kesehatan mampu menghasilkan laba ditahan sebesar 1.

Sementara pada tahun 2015, rasio X2 mengalami penurunan dari tahun sebelumnya yaitu menunjukkan nilai 0,63 yang artinya setiap Rp.1,00 Total Aset yang dimiliki oleh BPJS Kesehatan mampu menghasilkan laba ditahan sebesar 0,63.

Tabel 4. Perhitungan Rasio X2 pada BPJS Kesehatan 2014-2018 (Dalam Jutaan Rupiah)

\begin{tabular}{rrrc}
\hline Tahun & Laba ditahan & \multicolumn{1}{c}{ Total Aset } & \multicolumn{1}{c}{ X2 } \\
\hline 2014 & -3.309 .144 & -3.309 .144 & 1,000000 \\
2015 & -5.760 .071 & -9.069 .216 & 0,635123 \\
2016 & 508.434 & -8.560 .782 & $-0,059391$ \\
2017 & -14.464 .471 & -23.025 .252 & 0,628200 \\
2018 & -11.687 .563 & -34.712 .814 & 0,336693 \\
\hline
\end{tabular}

Sumber: Data diolah dari BPJS

Di tahun 2016, rasio X2 mengalami penurunan kembali dari tahun sebelumnya yaitu menunjukkan nilai $-0,05$ yang artinya setiap Rp.1,00 Total Aset yang dimiliki oleh BPJS Kesehatan mampu menghasilkan laba ditahan sebesar -0,05. 
Dan pada tahun 2017, rasio X2 mengalami kenaikan dari negatif menjadi positif dari tahun sebelumnya yaitu menunjukkan nilai 0,62 yang artinya setiap Rp.1,00 Total Aset yang dimiliki oleh BPJS Kesehatan mampu menghasilkan laba ditahan sebesar 0,62.

Pada tahun 2018, rasio X2 mengalami kenaikan kembali dari tahun sebelumnya yaitu menunjukkan nilai 0,33 yang artinya setiap Rp.1,00 Total Aset yang dimiliki oleh BPJS Kesehatan mampu menghasilkan laba ditahan sebesar 0,33.

\section{Earning Before Interest and Tax to Total Assets} (X3)

Pada tahun 2014, rasio X3 sebesar -12,3 yang artinya setiap Rp.1,00 total aset dapat menghasilkan laba sebelum bunga dan pajak sebesar -12,3.

Di tahun 2015, rasio X3 mengalami kenaikan menjadi $-6,1$ yang artinya setiap Rp.1,00 total aset dapat menghasilkan laba sebelum bunga dan pajak sebesar-6,1.

Tabel 5. Perhitungan Rasio X3 pada BPJS Kesehatan 2014-2018 (Dalam Jutaan Rupiah)

\begin{tabular}{rrrr} 
Tahun & $\begin{array}{c}\text { Laba sebelum } \\
\text { Bunga dan Pajak }\end{array}$ & Total Asset & X3 \\
\hline 2014 & 40.767 .510 & -3.309 .144 & $-12,31965$ \\
2015 & 55.524 .379 & -9.069 .216 & $-6,122290$ \\
2016 & 74.333 .148 & -8.560 .782 & $-8,682985$ \\
2017 & 77.846 .641 & -23.025 .252 & $-3,380924$ \\
2018 & 92.231 .646 & -34.712 .814 & $-2,656991$ \\
\hline Sumber: Data diolah dari BPJS
\end{tabular}

Dan pada tahun 2016, rasio X3 mengalami penurunan menjadi $-8,6$ yang artinya setiap Rp.1,00 total aset dapat menghasilkan laba sebelum bunga dan pajak sebesar $-8,6$.

Pada tahun 2017, rasio X3 mengalami kenaikan menjadi $-3,3$ yang artinya setiap Rp.1,00 total aset dapat menghasilkan laba sebelum bunga dan pajak sebesar $-3,3$.

Sementara pada tahun 2018, rasio X3 mengalami kenaikan kembali menjadi $-2,6$ yang artinya setiap Rp.1,00 total aset dapat menghasilkan laba sebelum bunga dan pajak sebesar $-2,6$.

\section{Total Equity to Total Debt Ratio (X4)}

Pada tahun 2014, rasio nilai buku ekuitas terhadap buku hutang menunjukkan rasio X4 5,40 yang artinya setiap Rp.1,00 total hutang mampu dijamin oleh nilai buku ekuitas sebesar 5,40.

Di tahun 2015, rasio nilai buku ekuitas terhadap buku hutang menunjukkan rasio X4 1,98 yang artinya setiap Rp.1,00 total hutang mampu dijamin oleh nilai buku ekuitas sebesar 1,98 dan mengalami penurunan sebesar $3,42 \%$ dari tahun 2014.

Kemudian pada tahun 2016, rasio nilai buku ekuitas terhadap buku hutang menunjukkan rasio X4 1,87 yang artinya setiap Rp.1,00 total hutang mampu dijamin oleh nilai buku ekuitas sebesar 1,87 dan mengalami penurunan sebesar $0,11 \%$ dari tahun 2015 .

Tabel 6. Perhitungan rasio X4 pada BPJS Kesehatan 2014-2018 (Dalam Jutaan Rupiah)

\begin{tabular}{lcrc}
\hline Tahun & \multicolumn{1}{c}{$\begin{array}{c}\text { Nilai buku } \\
\text { ekuitas }\end{array}$} & $\begin{array}{c}\text { Nilai Buku } \\
\text { hutang }\end{array}$ & X4 \\
\hline 2014 & 8.402 .661 & 1.554 .493 & 5,405 \\
2015 & 8.536 .615 & 4.300 .765 & 1,984 \\
2016 & 10.344 .737 & 5.502 .894 & 1,879 \\
2017 & 10.161 .365 & 8.822 .254 & 1,151 \\
2018 & 10.124 .003 & 13.721 .768 & 0,737 \\
\hline
\end{tabular}

Sumber: Data diolah dari BPJS

Pada tahun 2017, rasio nilai buku ekuitas terhadap buku hutang menunjukkan rasio X4 1,15 yang artinya setiap Rp.1,00 total hutang mampu dijamin oleh nilai buku ekuitas sebesar 1,15. Nilai rasio tersebut merupakan hasil pembagian antara nilai buku ekuitas sebesar Rp. 10.161.365 dengan nilai buku hutang sebesar Rp. 8.822.254 dan mengalami penurunan sebesar $0,72 \%$ dari tahun 2016.

Dan pada tahun 2018, rasio nilai buku ekuitas terhadap buku hutang menunjukkan rasio X4 0,73 yang artinya setiap Rp.1,00 total hutang mampu dijamin oleh nilai buku ekuitas sebesar 0,73. dan mengalami penurunan sebesar $0,42 \%$ dari tahun 2017.

\section{Hasil Altman Z-Score Modifikasi pada BPJS Kesehatan Periode 2014-2018}

Setelah menghitung variabel-variabel yang digunakan di dalam model Altman Z-score modifikasi, maka langkah selanjutnya adalah memasukkan hasil tersebut ke dalam model persamaan dengan cara mengalikan hasil data di atas dengan nilai konstanta atau standar masing-masing variabel. Model persamaan dan hasil perhitungan berdasarkan Z-score modifikasi adalah:

$$
\begin{array}{r}
\text { Z-score }=3,25+6,56 \times 1+3,26 \times 2+ \\
6,72 \times 3+1,05 X 4
\end{array}
$$

Keterangan variabel: $\mathrm{X} 1=$ modal kerja/total, $\mathrm{X} 2=$ laba ditahan/total aset, X3 = penghasilan sebelum bunga dan pajak/total aset, dan $\mathrm{X} 4=$ nilai buku ekuitas/nilai buku total utang.

Tahap selanjutnya adalah menjumlahkan hasil perkalian masing-masing variabel di atas yang bertujuan untuk mengetahui hasil analisis prediksi kebangkrutan dengan metode altman z-score yang dimodifikasi. Hasil perhitungannya dapat dilihat dari Tabel 7. Berdasarkan tabel tersebut, terlihat BPJS Kesehatan telah mengalami financial distress mulai tahun 2014 hingga 2018. Data tersebut memberi gambaran agar manajemen BPJS Kesehatan mengambil langkah kebijakan yang tepat. Keterlambatan dan ketidak efektifan penanganan 
akan berdampak kepada perusahaan dapat mengalami kebangkrutan.

Tabel 7. Hasil Analisis dengan Metode Z-score modifikasi pada BPJS Kesehatan periode 2014-2018

\begin{tabular}{rcrrrrr} 
Tahun & $\begin{array}{c}\text { Kons- } \\
\text { tanta }\end{array}$ & \multicolumn{1}{l}{ X1 } & \multicolumn{1}{c}{ X3 } & X4 & Z-Score \\
\hline 2014 & 3,25 & $-5,48$ & 3,26 & $-82,7$ & 5,67 & $-76,1$ \\
2015 & 3,25 & $-0,30$ & 2,07 & $-41,1$ & 2,08 & $-34,0$ \\
2016 & 3,25 & $-2,41$ & $-0,19$ & $-58,3$ & 1,97 & $-55,7$ \\
2017 & 3,25 & 2,17 & 2,04 & $-22,7$ & 1,20 & $-14,1$ \\
2018 & 3,25 & 1,93 & 1,09 & $-17,8$ & 0,77 & $-10,8$ \\
\hline
\end{tabular}

Hasil perhitungan juga digambarkan dalam bentuk grafis seperti Gambar 2 yang menunjukkan nilai Z-score pada BPJS Kesehatan periode 20142018. Hasil perhitungan Z-score pada BPJS Kesehatan yang memiliki nilai terendah adalah pada tahun 2014 yaitu sebesar -79,3. Rendahnya nilai Zscore pada tahun 2014 ini disebabkan karena nilai variabel X3 memiliki rasio yang paling rendah yaitu sebesar -12,3 dibandingkan dengan tahun 2015-2018. Padahal variabel X4 memiliki nilai sebesar 5,6 yang merupakan nilai terbesar daripada tahun-tahun berikutnya. Namun hal ini tidak mempengaruhi nilai Z-score nya.

Selain itu pada tahun 2015 nilai Z-score mengalami kenaikan akan tetapi pada tahun 2016 nilai Z-Score kembali menurun menjadi $-59,0$. Penurunan ini disebabkan karena nilai variabel X2 yaitu laba ditahan, memiliki nilai paling tinggi dibandingkan tahun-tahun lainnya yaitu sebesar Rp. 508.434,24.

Pada tahun 2018 nilai Z-score mengalami kenaikan yang signifikan yaitu menjadi -14,1. Nilai tersebut merupakan kenaikan yang paling tinggi yang dicapai, meskipun masih memperoleh nilai Zscore di bawah batas ambang yang ditentukan. Kenaikan nilai dipengaruhi oleh $\mathrm{X} 4$ yang memiliki nilai terkecil dibandingkan tahun-tahun sebelumnya yaitu 0,73 .

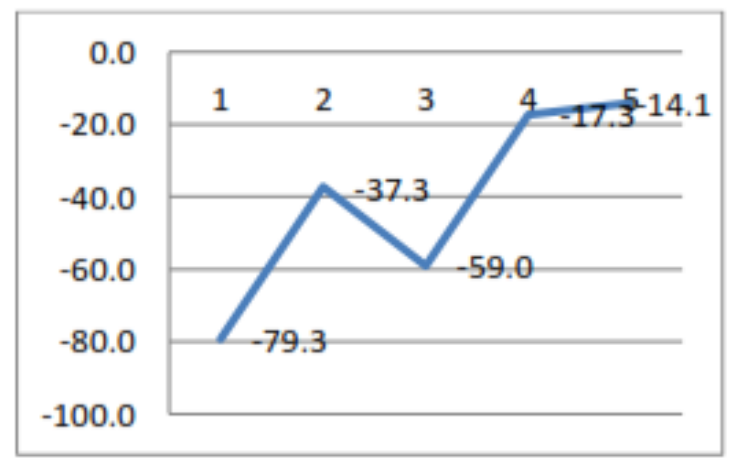

Gambar 2. Nilai Z-Score pada BPJS Kesehatan periode 2014-2018.

Apabila dilihat dari hasil perhitungan model Altman Z-score tampak bahwa Total Equity to Total Debt Ratio (X4) dan Retained Earnings To Total Asset (X2) berpengaruh lebih besar dalam menentukan nilai Z-score dibandingkan dengan variabel lainnya. Kenaikan laba ditahan juga mempengaruhi nilai Z-score atau potensi kebangkrutan suatu perusahaan. Apabila ditarik kesimpulan berdasarkan grafik selama 5 tahun, BPJS Kesehatan mengalami defisit yang kian membaik sehingga BPJS Kesehatan masih mempunyai harapan untuk dapat memperbaiki keuangannya.

BPJS Kesehatan, bagaimanapun, tidak akan berada di atas nilai cut-off. Hal ini disebabkan karena BPJS Kesehatan adalah perusahaan milik negara yang secara normatif tidak sewajarnya apabila memiliki profit besar. BPJS Kesehatan merupakan Badan Hukum Publik yang bertanggung jawab langsung kepada Presiden dan memiliki tugas untuk menyelenggarakan Jaminan Kesehatan Nasional bagi seluruh rakyat Indonesia.

Sumber dana BPJS Kesehatan adalah dari pemerintah dan peserta yang membayar iuran. Dengan demikian pemilik BPJS Kesehatan adalah pemerintah dan peserta program jaminan sosial, termasuk di dalamnya orang asing yang bekerja sekurang-kurangnya enam bulan di Indonesia. Mempertimbangkan hal tersebut, maka posisi ideal nilai Z-score BPJS Kesehatan seharusnya berada di area abu-abu yang meskipun memiliki profit terbatas, tetapi masih dapat membayarkan klaim layanan kesehatan hingga waktu yang akan datang.

\section{Faktor Internal yang Memengaruhi Financial} Distress pada BPJS Kesehatan

\section{Biaya Finansial yang Tinggi}

Program JKN didukung pendanaannya melalui iuran yang dibayarkan masyarakat sebagai peserta kepada BPJS Kesehatan sebagai lembaga yang bertanggungjawab. Iuran masyarakat ini kemudian disebut sebagai DJS Kesehatan. Iuran yang dibayarkan masyarakat ini merupakan dana amanat masyarakat yang akan digunakan membayar biaya manfaat atas pelayanan kesehatan yang diberikan oleh fasilitas kesehatan serta untuk membiayai operasional program jaminan sosial.

Pada tahun 2014, BPJS Kesehatan sudah mencatatkan kekurangan anggaran sebesar Rp 3,3 triliun. Berdasar kondisi tersebut, Pemerintah memutuskan untuk menyuntikkan Penyertaan Modal Negara (PMN) sebesar Rp 5 milyar pada 2015. Suntikan dana Pemerintah terbagi dalam dua tahap, yakni tahap pertama sebesar Rp 3,5 milyar dan tahap kedua Rp 1,5 milyar.

Kondisi keuangan BPJS Kesehatan pada tahun 2015 ternyata masih mencatatkan kekurangan anggaran. Kekurangan yang terjadi bahkan mencapai Rp 5,7 triliun. Pemerintah pun kemudian kembali menyuntikkan PMN lebih besar lagi mencapai Rp 5 triliun.

Pada tahun 2016, kondisi keuangan BPJS Kesehatan belum membaik. Kekurangan anggarannya memang sedikit lebih kecil dibanding 
2015, yakni mencapai Rp 9,7 triliun. Pemerintah kemudian memutuskan untuk menyuntikkan PMN sebesar Rp 6,8 triliun.

Adapun, pada tahun 2017 BPJS Kesehatan masih mencatatkan kekurangan anggaran sebesar Rp 9,8 triliun, dan Pemerintah hanya menganggarkan PMN sebesar Rp 3,6 triliun.

Sementara itu, pada tahun 2018 BPJS Kesehatan masih mencatatkan kekurangan anggaran mencapai Rp 9,1 triliun. Pemerintah kemudian menganggarkan cadangan anggaran dari APBN sebesar Rp 10, 3 triliun.

Penanganan defisit keuangan BPJS Kesehatan tahun 2015-2018 dilakukan sebagai berikut: tahun 2015 dan 2016 diatasi dengan Penyertaan Modal Negara kepada BPJS Kesehatan sedangkan tahun 2017 dianggarkan APBN dalam pos belanja lain-lain dan tahun 2018 berasal dari dana cadangan APBN.

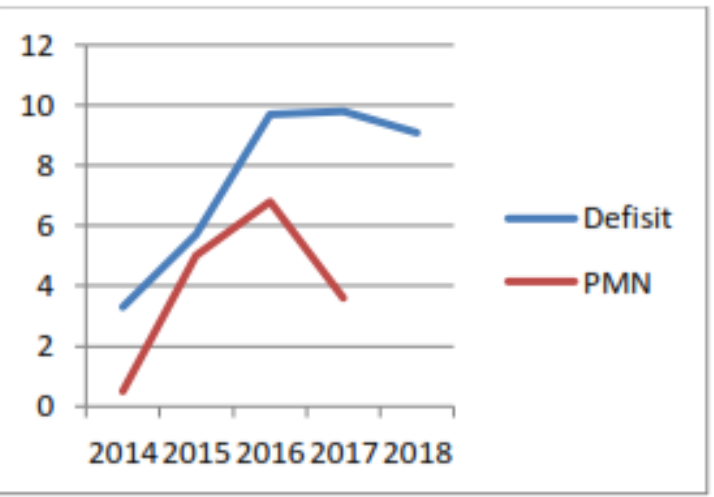

Gambar 3. Defisit dan Penyertaan Pemerintah ke BPJS Kesehatan 2014-2018. Sumber: BPJS Kesehatan 2018

Dilihat dari grafik tersebut, intervensi Pemerintah melalui PMN ternyata tidak efektif, karena masih belum mampu menyelesaikan masalah kekurangan anggaran yang terjadi selama 5 tahun terakhir. Dengan demikian perlu adanya perbaikan secara internal yang harus dilakukan oleh BPJS Kesehatan. Setidaknya ada 3 (tiga) hal yang terkait:

Pertama, struktur iuran yang masih underpriced (di bawah perhitungan aktuaria). Hal ini telah terjadi pada tahun 2016. Seharusnya iuran peserta BPJS Kesehatan ditentukan dengan mengikuti perhitungan aktuaria.

Kedua, banyak Peserta Bukan Penerima Upah (PBPU) mandiri/informal yang mendaftar pada saat yang bersangkutan sakit. Akan tetapi, setelah mendapat layanan kesehatan mereka berhenti membayar iuran kepesertaan yang dalam arti lain, menunggak biaya iuran setiap bulannya.

Ketiga, tingkat keaktifan peserta PBPU cukup rendah, hanya sekitar 54\%. Pada sisi lain, tingkat kepuasan sangat tinggi terjadi untuk layanan kesehatan yang sudah dirasakan pada penyakit yang membutuhkan biaya mahal.

Tingkat pengumpulan (kolektibilitas) iuran yang masih rendah di antaranya disebabkan karena rendahnya kedisiplinan peserta mandiri untuk membayar iuran secara teratur. Banyak peserta yang baru mulai membayar iuran pada saat akan menggunakan layanan BPJS Kesehatan. Kondisi ini makin diperburuk karena peserta yang hanya membayar iuran saat akan menggunakan layanan tersebut kemudian berhenti membayar iuran setelah menerima manfaat.

Pada tahun 2018, pemerintah melalui Kementrian Kesehatan belum berencana menaikkan iuran BPJS Kesehatan kendati mengalami defisit. Besaran iuran yang harus dibayarkan peserta masih tetap merujuk pada peraturan lama, yaitu Peraturan Presiden No 19 Tahun 2016.

Perhitungan iuran yang masuk didasarkan kepada berapa banyaknya jumlah peserta yang dikelompokan berdasarkan jenis: Penerima Bantuan Iuran (PBI), Pekerja Penerima Upah (PPU), Pekerja Bukan Penerima Upah (PBPU) dan Bukan Pekerja (BP). PBI termasuk peserta yang tergolong kurang mampu sehingga berada dalam fasilitas kesehatan kelas III sementara PPU, PBPU dan BP berada dalam fasilitas kesehatan kelas II dan kelas I.

\section{Faktor Eksternal yang Memengaruhi Financial Distress pada BPJS Kesehatan}

\section{Peserta BPJS Kesehatan}

Semua negara anggota World Health Organization (WHO), termasuk Indonesia berkomitmen untuk mencapai Universal Health Coverage (UHC) sejak tahun 2005. UHC atau dalam bahasa Indonesia dikenal dengan Jaminan Kesehatan Semesta, merupakan sistem kesehatan yang memastikan setiap warga di dalam populasi telah memiliki akses yang adil dalam pelayanan kesehatan promotif, preventif, kuratif, dan rehabilitatif yang bermutu dengan biaya yang terjangkau.

Indonesia mempunyai target sudah mencapai UHC pada tahun 2019. Dengan target tersebut maka hal yang diperlukan adalah dengan memberikan layanan kesehatan yang berkualitas melalui program Jaminan Kesehatan Nasional (JKN) yang dikelola oleh BPJS Kesehatan. Target pencapaian adalah sekitar $95 \%$ atau sejumlah 257,5 juta jiwa penduduk Indonesia yang sudah menjadi peserta JKN. Berdasarkan data BPJS Kesehatan tanggal tahun 2018, ada 208 juta jiwa atau dalam persentase sebesar $78 \%$ yang sudah menjadi peserta JKN.

Mengacu kepada paparan Direksi BPJS Kesehatan di awal 2018, upaya yang dilakukan BPJS Kesehatan masih tidak banyak berubah. BPJS Kesehatan masih fokus memberikan sosialisasi kepada warga, dan mendorong para stakeholders untuk aktif dalam mengoptimalkan pelaksanaan program JKN-KIS.

Berdasarkan laporan auditan Dana Jaminan Sosial (DJS) periode 2014-2018, DJS Kesehatan mengalami kesulitan keuangan yang dicerminkan dari besaran kewajiban pembayaran klaim layanan 
kesehatan masih lebih tinggi dari pada kemampuan BPJS Kesehatan dalam mengumpulkan penerimaan dari iuran peserta.

Kondisi lainnya adalah dalam lima tahun terakhir juga, BPJS Kesehatan hanya mampu menambah jumlah kepesertaan JKN-KIS total sebanyak 74,63 juta orang. Angka ini jika dirata-rata, akan menunjukkan jumlah peserta yang berhasil didaftarkan BPJS Kesehatan mencapai 1,49 juta orang per bulan di seluruh Indonesia.

Mempertimbangkan hal-hal tersebut, dan dengan melihat kinerja keuangan BPJS Kesehatan selama 5 tahun ini, lebih baik target mencapai UHC diundur sampai Desember 2020. Setidaknya terdapat empat hal yang akan menyebabkan target kepesertaan program JKN-KIS sulit dicapai: pertama, sosialisasi JKN oleh BPJS Kesehatan masih belum memadai. Diperlukan upaya-upaya yang lebih konkret agar rakyat mengetahui aturan dan manfaat JKN dengan jelas. Kedua, meningkatkan pelayanan JKN di rumah sakit. Tidak dapat dipungkiri, saat ini masih banyak keluhan dari masyarakat perihal pelayanan JKN. Kondisi itu akhirnya membuat citra dari JKN turun. Dan ketiga, masih lemahnya penegakan hukum bagi badan usaha yang belum mendaftarkan para pekerjanya ke BPJS Kesehatan. Koordinasi antara BPJS Kesehatan, pemerintah daerah dan Kejaksaan masih perlu untuk ditingkatkan lagi.

Kendala-kendala yang masih dihadapi BPJS Kesehatan menurut Wakil Direktur Trade Union Right Center (TURC) Andriko Otang, yaitu masih terjadi tumpang tindih antara data peserta PBI dan peserta Jaminan Kesehatan Daerah (Jamkesda); dan jumlah peserta PBI lebih besar dibandingkan dengan peserta yang merupakan pekerja penerima upah.

\section{KESIMPULAN}

Berdasarkan hasil analisis dan pembahasan, berikut ini diberikan beberapa simpulan.

1. Faktor internal (biaya finansial yang tinggi) berpengaruh terhadap terjadinya financial distress, yakni pendapatan yang rendah harus menanggung beban yang tinggi, sehingga diperlukan dana tambahan dari pemerintah.

2. Faktor internal (iuran Peserta) berpengaruh terhadap terjadinya financial distress, yakni iuran peserta merupakan dana utama BPJS kesehatan yang digunakan untuk menanggung beban jaminan kesehatan terhadap pelayanan yang diberikan.

3. Faktor ekternal (peserta BPJS Kesehatan) berpengaruh terhadap terjadinya financial distress, yakni terkait dengan perluasan sosialisasi dan peraturan kepesertaan.

4. Faktor eksternal (campur tangan pemerintah) berpengaruh terhadap terjadi financial distress, yakni peraturan pemerintahlah yang mengatur dari sisi kenaikan iuran hingga perluasan wilayah melalui pemerintah daerah.

\section{Saran Teoritis}

1. Melakukan sosialisasi program JKN/KIS secara maksimal. BPJS kesehatan perlu melakukan sosialisasi program JKN kepada masyarakat semaksimal mungkin, untuk memberikan pemahaman yang komprehensif tentang hak dan kewajiban masyarakat sebagai peserta program;

2. Memperbaiki layanan. BPJS Kesehatan perlu memperbaiki kualitas layanan kesehatan kepada masyarakat baik dari sisi sarana maupun prasarana

3. Menghimbau kepatuhan hukum pengusaha. BPJS Kesehatan perlu menghimbau dan mendorong kepatuhan para pimpinan perusahaan untuk segera mendaftarkan pekerjanya menjadi peserta Program JKN/KIS;

4. Memperbaiki koordinasi dengan stakeholders. BPJS perlu melakukan koordinasi atau kerja sama yang komprehensif dengan pemerintah daerah dan lembaga lain yang terkait, sehingga satu sama lain saling mendukung untuk mencapai UHC;

5. Memperbaiki keakuratan data peserta. BPJS Kesehatan perlu terus melakukan verifikasi dan validasi data peserta (baik PBI maupun Jamkesda), agar tidak terjadi kepesertaan ganda atau sebaliknya (mengabaikan masyarakat yang sebenarnya berhak menerima bantuan iuran)

\section{DAFTAR PUSTAKA}

Anderson (2013). How to manage Both Sides of a Balance Sheet to Maximize Wealth: The Value of Debt. New Jersey: John Wiley and Sons Inc.

Atmaja, L. S. (2008). Teori dan Praktek Manajemen Keuangan. Yogyakarta: Andi.

Azwar, S. (2007). Metode Penelitian. Jogjakarta: Pustaka Pelajar.

Brigham, E., \& Houston, J. F. (2001). Manajemen Keuangan II. Jakarta: Salemba Empat.

Irwandy (2016). Kajian Literature: Evaluasi Pelaksanaan Program Jaminan Kesehatan Nasional Di Indonesia. Jurnal Kebijakan Kesehatan Indonesia, 110-114.

Kurniawan, Y. T. (2017). Faktor-Faktor dan Pola Hubungannya yang Mempengaruhi Pemanfaatan Jaminan Kesehatan Nasional (JKN) Oleh Keluarga Miskin. Jurnal Cakrawala, 83-93.

Nindita, M. K., \& Nur, K. I. (2014). Prediction on Financial Distress of Mining Companies Listed in BEI Financial Variabel and Non-Financial Variabels, European Journal of Business and Management, Vol. 6 No.34.

Nugroho, Mawardi, \& Dwi. (2012). Analisis Prediksi Financial Distress dengan Menggunakan Model Altman Z-Score Modifikasi 1995: Studi Kasus Pada Perusahaan Manufaktur Yang Go Public di Indonesia Tahun 2008-2010. Semarang: Universitas Diponegoro.

Platt, H., \& Platt, M. B. (2002). Predicting Financial Distres. Journal of Financial Service Professionals. 
Radifan (2015). Analisis Pengaruh Mekanisme Good Corporate Governance Terhadap Kemungkinan Financial Distress. Fakultas Ekonomika dan Bisnis. Ramadhani, \& Lukviarman (2009). Perbandingan Analisis Prediksi Kebangkrutan Menggunakan Model Altman Pertama, Altman Revisi, dan Altman Modifikasi dengan Ukuran dan Umur Perusahaan sebagai Variabel Penjelas (Studi pad a Pemsahaan Manufaktur yang Terdaftar di Bursa Efek Indonesia). Jurnal Siasat Bisnis, 15-28.

Sugiyono, P. D. (2016). Metode Penelitian Manajemen. Metode Penelitian Manajemen, pp. 35-36. Bandung: Alfabeta. 